IZA DP No. 7106

Corruption, Shadow Economy and Income Inequality: Evidence from Asia

Saibal Kar

Shrabani Saha

December 2012 


\title{
Corruption, Shadow Economy and Income Inequality: Evidence from Asia
}

\author{
Saibal Kar \\ Centre for Studies in Social Sciences, Calcutta \\ and IZA \\ Shrabani Saha \\ Edith Cowan University
}

\section{Discussion Paper No. 7106 \\ December 2012}

\author{
IZA \\ P.O. Box 7240 \\ 53072 Bonn \\ Germany \\ Phone: +49-228-3894-0 \\ Fax: +49-228-3894-180 \\ E-mail: iza@iza.org
}

Any opinions expressed here are those of the author(s) and not those of IZA. Research published in this series may include views on policy, but the institute itself takes no institutional policy positions. The IZA research network is committed to the IZA Guiding Principles of Research Integrity.

The Institute for the Study of Labor (IZA) in Bonn is a local and virtual international research center and a place of communication between science, politics and business. IZA is an independent nonprofit organization supported by Deutsche Post Foundation. The center is associated with the University of Bonn and offers a stimulating research environment through its international network, workshops and conferences, data service, project support, research visits and doctoral program. IZA engages in (i) original and internationally competitive research in all fields of labor economics, (ii) development of policy concepts, and (iii) dissemination of research results and concepts to the interested public.

IZA Discussion Papers often represent preliminary work and are circulated to encourage discussion. Citation of such a paper should account for its provisional character. A revised version may be available directly from the author. 
IZA Discussion Paper No. 7106

December 2012

\section{ABSTRACT \\ Corruption, Shadow Economy and Income Inequality: Evidence from Asia ${ }^{*}$}

A number of recent studies for Latin America show that as the size of the informal economy grows, corruption is less harmful to inequality. We investigate if this relationship is equally compelling for developing countries in Asia where corruption, inequality and shadow economies are considerably large. We use Panel Least Square and Fixed Effects Models for Asia to find that both 'Corruption Perception Index' and 'ICRG' index are sensitive to a number of important macroeconomic variables. We find that in the absence of the shadow economy, corruption increases inequality. However, with larger shadow economies in South Asia, the income inequality tends to fall.

JEL Classification: J48, K42, 017, 053

Keywords: corruption, inequality, shadow economy, panel data, South Asia

Corresponding author:

Saibal Kar

Centre for Studies in Social Sciences, Calcutta

R-1, B. P. Township

Kolkata 700094

India

E-mail: saibal@cssscal.org

\footnotetext{
Saibal Kar thanks School of Accounting Finance and Economics, Edith Cowan University for generous visiting support during which this research was undertaken. The paper benefited from presentation at SAFE Seminar, Perth. The usual disclaimer applies.
} 


\section{Introduction}

A series of important recent studies for the Latin American countries (Dobson and Ramlogan-Dobson, 2012a, b; 2010) show that corruption is less harmful to income inequality when the presence of informal sectors in such countries is factored in. These papers argue that the economic reasons behind the moderating effect of corruption on inequality are primarily two-fold. On the one hand, the institutional weaknesses in developing countries per se lead to growth and persistence of informal sector that in turn employs a large number of semi-skilled and unskilled workers. The growth of the informal sector is interpreted as an offshoot of economic reform. Reform demands greater compliance and adherence to stringent regulations from formal institutions thereby raising their cost and eventually pushing them to informal production and employment arrangements. On the other hand, the existence of corrupt regimes in a country tends to distribute jobs and projects that would not be there in less corrupt regimes. This also leads to more employment opportunities for those who would be otherwise unemployed. These factors cushion the adverse effect of reforms on income inequality depending on the spread and depth of the informal sector. In fact, a large number of studies analytically substantiate that the fact that growth of informal sector is largely influenced by economic reforms and corrupt governance (for example, Ulyssea, 2010; Dabla-Norris, 2008; De Soto, 2000; Dixit, 2004; Marjit, 2003; Marjit, Ghosh and Biswas, 2006, etc).

Since South and Central America, Sub-Saharan Africa and large parts of developing Asia all suffer from development deficits, considerable corruption and high 
incidence of shadow economies, it should be interesting to find out if evidence for Asia is as compelling as that reported for Latin America. Presently, we offer a detailed panel data analysis for 19 countries in Asia between 1995-2008 to observe the possible linkages between corruption and inequality, both being reportedly high under acceptable indices. To this end, we use Panel Least Square and Fixed Effects Model in the presence of the shadow economy to find that both 'Corruption Perception Index' and 'ICRG' index are sensitive to a number of important macroeconomic variables. These include, schooling at secondary and tertiary levels, size of the service sector, degree of trade openness, final public consumption expenditure, demographic distribution, etc. We also use a south Asian dummy to examine the impact of corruption on income inequality in the presence of large shadow economies - a predominant feature of south Asian countries. We find that, in the absence of the shadow economy corruption increases inequality. However, if the shadow economies in the South Asian countries are bigger, the income inequality tends to fall. More generally, we find that corruption increases income inequality in developing countries of Asia. In addition, the higher incidence of corruption leads to higher inequality in South Asian countries and the presence of large shadow economies reduces income inequality even if corruption rises at the margin. The rest of the paper is organized as follows. Section 2 discusses the available literature and section 3 offers methodology and data in adequate detail. Section 4 discusses the results and section 5 concludes.

\section{Literature Review}


Available evidence suggests that corruption and the size of the informal sector are complements or substitutes and may depend on the individual or aggregate income levels (e.g., Dutta, Kar and Roy, 2011; Dreher and Schneider, 2010; Friedman et al., 2000; Johnson, Kaufmann, and Zoido-Lobaton, 1998, etc). While cross-country interest on this issue is not uncommon, region-specific or country-specific evidence is relatively scant. Moreover, the evidence centers mainly on the 'informal sector', while some of these countries also host relatively large illegal economies generally termed as the 'shadow economy'. It is plausible that the dampening, and therefore unexpected (since most papers show that corruption raises inequality, such as, Ades and Di Tella, 1997; Gupta, Davoodi, and Alonso-Terme, 2002; Gyimah-Brempong and Munoz de Camacho, 2006; $\mathrm{Li}, \mathrm{Xu}$, and Zou, 2000, etc.) impact of corruption on inequality may or may not remain valid if one extends the concept of the informal sector to the shadow economy. Note that, the shadow economy includes activities that are often criminal, unreported, unrecorded, illegal or at least 'informal'. However, Schneider (2005) in this and several other studies suggest that the subject remains controversial mainly owing to a lack of uniformity in the definition adopted globally and the new innovations that keep adding to the complex maze of illegal activities. It is therefore not automatic that the expansion of the shadow economy dampens the level of income inequality in the same manner as one contemplates with growth of the informal economy. The extra-legal dimensions of the shadow economy are capable of cornering resources and raise inequality in contradiction to what has been argued generally. Therefore, the issue lends itself to empirical verification as we offer presently. The evidence of participation in the shadow economy in Asia is particularly compelling (for example, Chaudhuri, Schneider and 
Chattopadhyay, 2006 for India) and therefore it is natural to develop an econometric model for estimating the impact of corruption on inequality in the presence of sizable shadow economies. Recently Dutta, Kar and Roy (2012) study 20 Indian states to empirically show that higher corruption increases level of employment in the informal sector. Further, it shows that for higher levels of lagged state domestic product, the positive impact of corruption on the size of the informal sector is nullified.

Overall, these results are not unexpected since the shadow economy employs large number of people, works as a buffer and sustains livelihood. Nonetheless, the question of causal link, whether corruption leads to shadow economy or the pre-existing shadow economy leads to corrupt practices hints at the problem of endogeneity. We use instrumental variables such as life expectancy and military expenditure at the countrylevel to check for the robustness of these econometric models and indicate that it is the corruption in the aggregate that leads to growth and persistence of the shadow economy lowering income inequality as a consequence.

\section{Model, data and methodology}

In order to estimate the impact of corruption on inequality in the presence of shadow economy the model is structured as follows:

$$
I_{i, t}=\beta_{0}+\beta_{1} C P I_{i, t}+\beta_{2} S E_{i, t}+\beta_{3} C P I_{i, t} * S E_{i, t}+\delta X_{i, t}+\varepsilon_{i, t}
$$

where, $I$ is a measure of income inequality, $C P I$ is corruption, $S E$ is shadow economy and $X$ is a vector of explanatory variables used by most cross-country inequality studies capable of explaining a significant portion of the variation in income inequality. These include: log real GDP per capita (lnRGDPPC), government final consumption 
expenditure as a share of GDP (GFC), gross secondary school enrollment rate (SchoolS), gross tertiary school enrollment rate (SchoolT), share of service sector in total output (Service), exports plus imports as a share of GDP (Open), average of political rights plus civil liberties (Demo). ${ }^{1}$ Further, $\delta$ is vectors of coefficients, $\varepsilon$ is the error term and subscripts $i$ represents country and $t$ is time.

The coefficient $\beta_{3}$ captures the interaction effect of corruption and shadow economy on inequality, which is the main focus in this study. In addition, the partial effects of corruption and shadow economy on inequality are computed as follows:

$$
\begin{aligned}
& \frac{\partial I_{i, t}}{\partial C P I_{i, t}}=\beta_{1}+\beta_{3} S E_{i, t} \\
& \frac{\partial I_{i, t}}{\partial S E_{i, t}}=\beta_{2}+\beta_{3}^{\prime} C P I_{i, t}
\end{aligned}
$$

Equation (2a) is the marginal impact of corruption on inequality when the shadow economy is included in the model. If $\beta_{3}<0$, and the absolute value exceeds $\beta_{1}>0$ then equation (2a) implies that a one percentage point increase in corruption yields a negative impact on inequality as the size of the shadow economy increases. Conversely, if $\beta_{3}>0$ corruption increases inequality if the shadow economy grows with it. This is essentially the interaction term between corruption and shadow economy, which is the main focus of our analysis and therefore should be explained in detail. Stated alternatively, equation (2a) tests if the rise in corruption translating into a rise in the size of the shadow economy lowers income inequality. Similarly, equation (2b) is the marginal effect of shadow

\footnotetext{
1 The reasons behind inclusion of these variables are discussed in Reuveny and Li, 2003; GyimahBrempong and Munoz de Camacho, 2006 and Andres and Ramlogan-Dobson, 2011, for example.
} 
economy on inequality in the presence of corruption. If $\beta_{3}^{\prime}<0$ and exceeds $\beta_{2}>0$ then a one percentage point increase in the size of the shadow economy lowers inequality if it also leads to more corruption in the system.

The analytical basis for the relationship in (2a) is direct. If the prevalence and rise in corruption leads to development of the shadow economy it should create certain economic opportunities in a country that would not otherwise exist. These opportunities manifest themselves into income generating activities among workers and entrepreneurs in the shadow economy lowering inequality in response. Note that, the activities within the shadow economy undoubtedly stay outside the formal system and are mostly unreported. The activities do not generate tax revenue (but may generate bribes for sustaining an extra-legal system explaining the marginal effect in 2b) and is not factored in the growth accounting. Although there is gross underreporting in consumption expenditures as captured via census, activities in the shadow economy cannot be fully suppressed either physically or in terms of household data. Since unemployment benefit and other social security transfers are fairly minimal for these countries (see Tzannatos and Roddis, 2000 for global data on welfare transfers), sustaining a livelihood for poor people is often dependent on activities in the shadow economy and it is captured in various country-specific sample surveys, such as National Sample Survey (NSS) in India.

Next, we examine the relationship between corruption and inequality in the South Asian countries using the interaction term of corruption (CPI) and South Asian dummy (DSA) using equation (3).

$$
I_{i, t}=\gamma_{0}+\gamma_{1} C P I_{i, t}+\gamma_{2} D S A+\gamma_{3} C P I_{i, t} * D S A+\delta X_{i, t}+\varepsilon_{i, t}
$$


Differentiating equation (3) with respect to corruption shows the marginal impact of corruption as:

$$
\frac{\partial I_{i, t}}{\partial C P I_{i, t}}=\gamma_{1}+\gamma_{3} D S A
$$

Once again, $\gamma_{3}$ is the interaction term between corruption and inequality when the relation is tested for countries in South Asia alone (as a sub-set of developing Asian countries). The coefficient suggests that corruption increases inequality in south Asian countries (more) compared to non-South Asian countries. We expect $\gamma_{3}>0$ and $\left(\gamma_{1}+\gamma_{3}\right)>0$.

Subsequently, we incorporate the shadow economy variable to examine the role of informal sector in the South Asian countries. This is modeled as:

$$
I_{i, t}=\gamma_{0}+\gamma_{1} C P I_{i, t}+\gamma_{2} D S A+\gamma_{3} C P I_{i, t} * D S A+\gamma_{4} S E_{i, t}+\gamma_{5} C P I_{i, t} * S E_{i, t}+\delta X_{i, t}+\varepsilon_{i, t}
$$

Differentiating equation (5) with respect to corruption estimates the marginal impact of corruption on inequality in the presence of shadow economy as:

$$
\frac{\partial I_{i, t}}{\partial C P I_{i, t}}=\gamma_{1}+\gamma_{3} D S A+\gamma_{5} S E_{i, t}
$$

If the shadow economy plays a crucial role in reducing inequality in South Asian countries, then $\gamma_{5}<0$ and the absolute value of $\gamma_{5}$ should exceed $\left(\gamma_{1}+\gamma_{3}\right)$. In other words, the marginal impact of corruption is less positive and may become negative as the size of the shadow economy increases.

The empirical model is estimated on the basis of a sample of developing countries 
in Asia. ${ }^{2}$ Our dependent variable is inequality, which is measured by Gini coefficient. Data on Gini coefficient is drawn from the United Nations World Income Inequality Database (WIID) (UNU-WIDER, 2008). ${ }^{3}$ The subjective index of corruption is used as a principal measure, collected from Transparency International’s Corruption Perception Index (CPI). ${ }^{4}$ The CPI index is a composite index based on individual surveys from various sources. For simplicity and ease of exposition, the CPI has been converted into a scale from 0 (least corrupt) to 10 (most corrupt). Note that, we also use International Country Risk Guide (ICRG) corruption index for robustness check. It should be pointed out that both CPI and ICRG have been criticized for biases and are not completely free from errors. However, these are still the best data sets available for cross-country studies. In this regard, it is important to remind the reader that inequality has several sociological and psychological impacts on the people. For example, You and Khagram (2005) find that inequality increases perceived corruption. Thus, the perception-based indicators may already have factored in effects of inequality. The ICRG index is rescaled in the same manner as the CPI. Data for other explanatory variables are obtained from the World Bank’s World Development Indicators 2010 and Freedom House. Data on the shadow economy is drawn from Schneider (2007). The shadow economy is measured in terms of percentage of 'official' GDP. Shadow economy data from Schneider (2007) are the most comprehensive estimates obtained using unified method and have been used in many other studies (e.g., Dobson and Ramlogan-Dobson, 2012 and Layoza, Ovied and Serven, 2005). Table 1 provides the descriptive statistics of all variables included in the study.

\footnotetext{
${ }^{2}$ Countries included in the sample are: Bangladesh, China, Hong Kong, India, Indonesia, Iran, Israel, Jordon, Kuwait, Malaysia, Oman, Pakistan, Philippines, Saudi Arabia, Singapore, South Korea, Sri Lanka, Taiwan, Thailand, United Arab Emirates, and Yemen.

${ }^{3}$ See http://www.wider.unu.edu/research/Database/en_GB/database/ for details.

${ }^{4}$ See http://www.transparency.org/research/cpi/overview for details.
} 
[Table 1 ABOUT HERE]

In order to estimate the impact of corruption on inequality, our benchmark model (equation 1) is estimated with panel least square (PLS) and fixed effects (FE). Use of FE model is advantageous because it can control for unobserved time-invariant countryspecific effects. Instrumental variable estimation is used for addressing potential endogeneity. Following Chong and Calderon (2000), government military spending as a percentage of GDP is used as potential instrument for corruption. We also use life expectancy as another instrument for corruption. ${ }^{5}$ We test the instrument validity by using Sargan's test of over-identifying restrictions. Wald test is used to determine the significance of independent variables and the instrumental variables explain the mutual causality between corruption and income inequality.

\section{Results}

The regression fit of the scatter plots of GINI and CPI in Figure 1 suggests a positive relationship between Gini coefficient and corruption. In other words, higher levels of corruption are associated with higher levels of inequality. Figure 2 shows that an increase in the size of the shadow economy is associated with higher levels of corruption. On the other hand, Figure 3 illustrates that large shadow economy increases inequality in the developing countries of Asia.

\footnotetext{
${ }^{5}$ Corruption can have impact on life expectancy as Mauro (1998) points out that more corrupt government spends less on health and education. Correlation between life expectancy and corruption is 0.25 . As life expectancy cannot directly affect income inequality but may affect indirectly via corruption.
} 


\section{[FIGURE 1 to FIGURE 3 ABOUT HERE]}

The estimated panel results for the relationship between inequality and corruption are presented in this section. First, we focus on the results of CPI and then re-estimate the results using ICRG index. The next section presents results using two-stage least squares (TSLS) followed by the regression analysis for the South Asian countries. The model diagnostics provide no case for concern and all models indicate a good fit to the data.

Table 2 reports panel least square and fixed effect results of estimating equation (1). CPI is used as the dependent variable. Column (1) shows that corruption coefficient is positive and significant at 1 percent level indicating that an increase in corruption increases the Gini coefficient i.e. income inequality. This supports the conventional view that corruption is indeed deleterious for inequality. The positive SE coefficient in column (2) suggests that the shadow economy by itself significantly increases inequality in the Asian countries. However, the interaction effect of SE and CPI on inequality is negative and significant. The interaction effect (column 3) of shadow economy on inequality at the mean score of corruption of 5.899 is 0.623 , which is statistically significant at $1 \%$ level. It suggests that a one-point standard deviation increase in shadow economy increases income inequality by 6.56 points at the mean CPI score of 5.899. However, the impact of shadow economy shows some mixed results at different levels of corruption. If a country is less corrupt, then a high share of shadow economy is associated with greater inequality. But if a country is highly corrupt then the existence of a large shadow economy reduces inequality. These empirical findings appropriately describe the theoretical conjectures discussed in section 3 . 
[TABLE 2 ABOUT HERE]

The interaction effect of corruption on inequality at the mean SE score of 27.925\% is 1.452 . This implies that a one standard deviation increase in corruption index increases inequality by 3.52 points, or 0.68 standard deviations in the Gini coefficient at the mean SE score. The result indicates that the interaction effect of corruption has a significant impact on increasing inequality given an average sized shadow economy. However, the interaction effect of corruption is not always positive. It produces both positive and negative effects on inequality in the polar cases. The partial effect estimates (following Saha et al., 2009) the shadow economy and corruption interaction at various levels of SE starting from $10 \%$ to $70 \%$ of the GDP share and the results are reported in Table 3. For example, the estimated coefficient of 1.859 of the interaction term at SE $=$ $10 \%$ indicates that when the shadow economy is rather small, an increase in corruption increases inequality. In contrast, when the shadow economy is quite large (i.e. SE $=70 \%$ of GDP) a one-unit increase in corruption reduces inequality by 9.270 points. The threshold point of SE is reached between $10 \%$ and $20 \%$ of GDP share. Thus, corruption increases inequality when the level of shadow economy is very small. As a country crosses the threshold greater corruption decreases inequality with larger shadow economies. This result indicates that the shadow economy alters the relationship between corruption and inequality. For Asia, this conforms to the Latin American studies by Dobson and Ramlogan-Dobson (2010) and Andres and Ramlogan-Dobson (2011). 


\section{[TABLE 3 ABOUT HERE]}

Columns (4) and (5) estimate the impact of openness on inequality in the presence of corruption and the results show that globalization increases inequality at the mean score of corruption in the Asian countries. This result is valid even in the presence of shadow economy (column 5). Control variables such as log GDP per capita, tertiary school enrollment and share of service sector to GDP show negative signs. This indicates that a higher level of income per capita, tertiary enrollment and service sector reduces inequality. Note that, coefficients for government consumption expenditure, secondary school enrollment and democracy are positive suggesting that higher levels of each of these factors increase inequality. This further implies that the countries are unequal to begin with and new resources generated via public expenditure, democracy and access to education are cornered by a few exacerbating income inequality in the process.

Fixed effects (FE) results are in columns (6)-(10) of Table 2. These results are consistent with the panel estimates. In particular, the shadow economy coefficient is positive but not significant, the coefficient on corruption is positive and significant, and the corruption-shadow economy coefficient is negative and significant. The results support the view that the impact of corruption on inequality depends on the size of the shadow economy. In the absence of shadow economy, corruption increases inequality and it falls as the shadow economy expands. Furthermore, if the economy is more 'open' (as measured by the degree of trade openness) it increases inequality for the most corrupt countries in Asia. We also estimate the random effects and the results remain same. ${ }^{6}$

\footnotetext{
${ }^{6}$ The results are not reported here and available on request.
} 
ICRG Index

For the next step, we estimate equation (1) using ICRG index for perception of corruption and results are very similar to that of CPI (Table 4). The previous results show that a significant partial correlation between corruption and inequality exists, along with other control variables. However, Gini coefficient is likely to increase corruption and the OLS estimation may overestimate/underestimate the corruption impact on inequality.

Finally, we use the instrumental variables (IV) approach to investigate a causal relation between corruption and inequality. Life expectancy and military expenses as a percentage of GDP are used as instruments for corruption.

\section{[TABLE 4 ABOUT HERE]}

We show that these variables perform remarkably well from a statistical point of view. The model passes the Sargan test in all cases (Table 5) suggesting that both military expenditure as a percentage of GDP and life expectancy are good predictors of corruption. The TSLS estimates confirm the results of the PLS estimations (Table 2), that a higher level of corruption is significantly associated with higher inequality. In addition, the interaction effects result for CPI and SE is also consistent with the PLS results. This finding is robust and provides strong evidence that higher corruption unambiguously increase inequality in the developing countries in Asia. Moreover, the shadow economy alone increases inequality in the most corrupt countries of Asia. 


\section{[TABLE 5 ABOUT HERE]}

The estimated results of the SA dummy however, show that South Asian countries are more equal than the rest of the developing countries in Asia (Table 6). The estimated coefficient of South Asia dummy is negative and highly significant (columns 20 and 21). The results clearly indicate that the problem of inequality is less serious in South Asian countries, compared to the other regions. However, corruption increases inequality more in South Asian countries. The results in column (22) of Table (6) show that the marginal impact of corruption in South Asian countries is $1.413+(1.810 * 1)=3.223$ and while for the non-South Asian countries it is 1.413. In other words, a one unit rise in corruption (CPI) leads to a rise in the Gini coefficient by approximately 3.2 in South Asian countries. If the ICRG measure of corruption is used, the marginal impacts are small i.e. Gini coefficient rises by 0.17 (column 23). The results illustrate that more corruption increases inequality in South Asian countries to a greater extent. It should be interesting to point out that South Asian countries are more equal than other countries in Asia but corruption makes them more unequal.

\section{[TABLE 6 ABOUT HERE]}

Columns (24) and (25) estimate the interaction effects between corruption and SA dummy and corruption and SE, based on equation (5). Corruption-shadow economy interaction term is negative and significant indicating that the marginal impact of corruption decreases as the informal sector becomes larger. For example, a country with average size of informal sector of $28 \%$ of GDP the marginal impact of CPI on inequality 
is $4.809+0.032 * 1-0.183 * 28=-0.283$. Thus, a one-point rise in corruption (CPI) decreases the Gini coefficient by 0.283 . For ICRG measure of corruption, the marginal impact on inequality is much greater $(-2.149)$ for the average size of shadow economy. Interestingly, in the absence of the shadow economy corruption increases inequality but large shadow economy in South Asian countries tend to reduce the income gap between the rich and poor. This echoes the result reported in Table 3. The marginal impacts of CPI (ICRG) on inequality for the average size of shadow economy for the list of Asian countries are shown in Table 7. The results illustrate that except India, CPI decreases inequality due to the existence of large shadow economy in South Asian countries. For ICRG index magnitudes of the negative effects are much stronger for South Asian economies indicating that large size of shadow economy helps reducing the income gap even when corruption increases.

\section{[TABLE 7 ABOUT HERE]}

\section{Concluding Remarks}

Democracy in poor countries is often a rather problematic choice, but is the only political, social and economic first best. The share of problems that the poor countries face owing to the nature of governance can be vexing at times. Economic inequality, high degrees of informality and large shadow economies are persistent features of the global South. In addition, the spread and depth of corrupt practices in most of these countries has created conditions whereby free and fair economic activities have often moved to the backseat. Along with it, the enforcement mechanisms usually function 
poorly both due to lack of resources to monitor and due to certain strategic choices made by the government. The governmental failure in creating 'formal' economic opportunities often becomes a source of discontent among the governed. To pacify political unrest, the government strategically avoids monitoring and confrontation with extra-legal activities unless particularly forced by formal lobbies to do so. We make an effort to measure whether a connection can be established between the degree of corruption faced by economic agents in the poor countries of Asia and the level of income inequality prevailing in respective countries.

We generated data for a set of 19 countries in Asia to see if corruption as measured by the perception indicators (Transparency International) leads to greater income inequality in these countries given the share of the shadow economy. As reported previously for Latin American countries, we too find that beyond a share of $30 \%$ of the GDP coming from the shadow economy the level of inequality falls with corruption. It should be noted that, existence of shadow economies or large informal sectors do not necessarily lead to more equity in income distribution. Large shadow economies often lead to cornering of resources and extreme exploitation of workers who do not make it to the thin formal sector, where standard rules and regulations apply. The present set of results suggests that income distribution in the presence of a shadow economy is not so dismal when corruption influences growth of such economies. The present data set does not allow us to explore whether the rule of law is further a product of deliberate misuse of governance as discussed above, or whether it is a product of the structural deficiencies at the country level which hinders growth and development of more formal businesses. While this may be a topic of related research in future, presently we find that the handful 
of south Asian countries show lesser degrees of income dispersion when the interaction with the corruption perception is not taken into account. However, the effect becomes negative (meaning lower inequality) and significant, when the share of shadow economy interacts with the corruption indicators. This suggests that the spread of the shadow economy in the south Asian countries may have raised earnings among individuals and groups who otherwise would remain unemployed. The comparable ICRG corruption index has been used as a check for the results based on Transparency International. It seems that the results continue to be unidirectional in most cases, implying that a rise in the level of corruption lowers inequality via expansion of the shadow economy.

It should be clarified finally that we have reported results from a partial equilibrium exercise, where income inequality is the only variable of interest. It is selfexplanatory that explosion of corrupt behavior and the deepening of the shadow economy in a country are far from desired policies that a social planner concerned with economic inequality may consider adopting. Although more corruption leads to lower income inequality by allowing activities in the shadow economy as we see both from a crosssection and a panel, but this cannot be the conscious choice for governments in power. We also cannot ignore the economic trade-off that these countries continue to make. Strong economic and political tension exists between extra-legal activities, lower growth and lower inequality and these are posed against economic growth via proliferation of formal economy where rules are much more stringent. It depends on the political choices made by these sovereign countries, as to which would be the acceptable path in future. 


\section{References}

Ades, A., \& R. Di Tella (1997). The new economics of corruption: A survey and some results, Political Studies, 45, 3, 496-515.

Andres, A.R., C. Ramlogan-Dobson (2011), Is corruption really bad for inequality? evidence from Latin America, Journal of Development Studies, 47, 959-976.

Chaudhuri, K, F. Schneider and S. Chattopadhyay (2006), The size and development of the shadow economy: An empirical investigation from states of India, Journal of Development Economics, 80, 428- 443.

Chong, A. and C. A. Calderon (2000), Institutional quality and income distribution, Economic Development and Cultural Change, 48, 4, 761-786.

Dabla-Norris, E., M. Gradstein and G. Inchauste (2008), What Causes Firms to Hide Output? The Determinants of Informality, Journal of Development Economics 85, 1-2, $1-27$.

Dobson, Stephen and Carlyn Ramlogan-Dobson (2012), Inequality, corruption and the informal sector, Economics Letters, 115, 104-107

Dobson, S.M., C Ramlogan-Dobson (2010), Is there a trade-off between inequality and corruption? Evidence from Latin America, Economics Letters, 107, 102-104.

Dobson, Stephen and Carlyn Ramlogan-Dobson (2012), Why is Corruption Less Harmful to Income Inequality in Latin America? World Development, 40, 8, 1534-1545.

De Soto, Hernando (2000): The Mystery of Capital. USA: Basic Books.

Dixit, A (2004): Lawlessness and Economics: Alternative Modes of Governance, NJ: Princeton University Press.

Dreher, A., \& F. Schneider (2010). Corruption and the shadow economy: An empirical analysis, Public Choice, 144, 2, 215-238.

Dutta, Nabamita, Saibal Kar and Sanjukta Roy (2012), Informal Sector and Corruption: An empirical Investigation for India, forthcoming, International Review of Economics and Finance.

Friedman, E, Johnson, J, Kaufmann, D and Zoido-Lobaton, P (2000), Dodging the grabbing hand: the determinants of unofficial activity in 69 countries, Journal of Public Economics 76, 459-493.

Gupta, S, Davoodi, H and Alonso-Terme, R (2002), Does Corruption Affect Income Inequality and Poverty? Economics of Governance, 3, 1, $23-45$. 
Gyimah-Brempong, K., S. Muñoz de Camacho (2006), Corruption, growth, and income distribution: are there regional differences? Economics of Governance, 7, 245-269.

Johnson, S, D. Kaufman, A. Shleifer (1997), The Unofficial Economy in Transition, Brookings Papers on Economic Activity, Economic Studies Program, The Brookings Institution, 28, 2, 159-240.

Kaufmann, D. and S-J Wei (1999), Does 'Grease Money' Speed up the Wheels of Commerce? National Bureau of Economic Research Working Paper 7093, Cambridge MA.

Laoyza, N V, Oviedo, A M, and Serven, L (2005). The impact of regulation on growth and informality, World Bank Staff papers, 3623.

Li, H., L. C. Xu, \& H. F. Zou (2000), Corruption, income distribution, and growth. Economics and Politics, 12, 2, 155-181.

Marjit, S. (2003): Economic reform and Informal wage - A General Equilibrium Analysis, Journal of Development Economics, 72, 1, pp 371-378.

Marjit, S., S. Ghosh and A Biswas (2007), Informality, Corruption and Trade Reform, European Journal of Political Economy, 23, 777-789

Reuveny, R., Q. Li, (2003), Economic openness, democracy and income inequality: an empirical analysis, Comparative Political Studies, 36, 575-601.

Saha, S., R. Gounder and J. J. Su (2009), The interaction effect of economic freedom and democracy on corruption: A panel cross-country analysis, Economics Letters, 105, 2, 173-176.

Schneider, F (2007), Shadow economies and corruption all over the world: new estimates for 145 countries.

http://www.lawrence.edu/fast/finklerm/ShadEconomyCorruption_July2007.pdf

Schneider, F (2005), Shadow economies around the world: what do we really know?

European Journal of Political Economy, 21, 598- 642.

Schneider, F (2004), The size of the shadow economies of 145 countries all over the world: first results over the period 1999 to 2003, Bonn: IZA DP No. 1431.

Tzannatos, Z and S. Roddis (1998), Unemployment Benefits, Social protection Discussion Paper series \# 9813, Social protection Unit, World Bank, Washington DC.

Ulyssea, G (2010), Regulation of entry, labor market institutions and the informal sector. Journal of Development Economics 91, 87-99. 
UNU-WIDER (2008), http://www.wider.unu.edu/wiid/wiid.htm.

World Bank, (2008), World Development Indicators CD-ROM, World Bank, Washington DC.

You, J.-S. and S. Khagram (2005), A Comparative Study of Inequality and Corruption, American Sociological Review, 70, 136-157. 
Table 1 Descriptive Statistics

$\begin{array}{lcccccccccc} & \text { GINI } & \text { CPI } & \text { ICRG } & \text { GDPPC } & \text { SCHOOLS } & \text { SCHOOLT } & \text { GFC } & \text { DEMO } & \text { OPEN } & \text { SE } \\ \text { Mean } & 39.441 & 5.899 & 6.184 & 8182.803 & 74.460 & 27.236 & 14.033 & 4.081 & 102.189 & 27.925 \\ \text { Median } & 38.400 & 6.600 & 6.250 & 1640.862 & 77.146 & 21.885 & 12.309 & 3.333 & 80.344 & 25.500 \\ \text { Maximum } & 50.600 & 10.000 & 8.500 & 40837.27 & 111.236 & 103.559 & 33.012 & 10.000 & 460.471 & 54.100 \\ \text { Minimum } & 29.000 & 0.600 & 2.500 & 122.095 & 27.709 & 2.559 & 4.364 & 0.001 & 0.309 & 13.100 \\ \text { Std. Dev. } & 5.171 & 2.425 & 1.439 & 11419.80 & 21.371 & 19.896 & 6.361 & 2.875 & 88.426 & 10.530 \\ \text { Skewness } & 0.244 & -0.466 & -0.443 & 1.353 & -0.292 & 1.438 & 0.983 & 0.323 & 2.084 \\ \text { Kurtosis } & 2.117 & 2.118 & 2.705 & 3.474 & 1.997 & 5.270 & 3.211 & 1.911 & 7.253 & 2.963 \\ \text { Observations } & 392 & 392 & 374 & 329 & 250 & 246 & 321 & 392 & 331 & 60\end{array}$


Table 2 Inequality, corruption and shadow economy: Income Inequality as the dependent variable

\begin{tabular}{|c|c|c|c|c|c|c|c|c|c|c|}
\hline & PLS (1) & PLS (2) & PLS (3) & PLS (4) & PLS (5) & FE (6) & FE (7) & FE (8) & FE (9) & FE (10) \\
\hline CPI & $\begin{array}{l}1.433^{* * *} \\
(4.241)\end{array}$ & $\begin{array}{l}-0.108 \\
(0.018)\end{array}$ & $\begin{array}{l}3.714 * * \\
(2.109)\end{array}$ & $\begin{array}{l}1.549 * * * \\
(5.887)\end{array}$ & $\begin{array}{l}5.211^{* * *} \\
(5.758)\end{array}$ & $\begin{array}{l}0.741^{* * *} \\
(3.600)\end{array}$ & $\begin{array}{l}-2.003^{* * *} \\
(15.687)\end{array}$ & $\begin{array}{l}9.756^{* * *} \\
(4.471)\end{array}$ & $\begin{array}{l}0.204 \\
(0.736)\end{array}$ & $\begin{array}{l}-4.681^{* * *} \\
(14.148)\end{array}$ \\
\hline LnGPPPC & $\begin{array}{l}-0.127 \\
(0.504)\end{array}$ & $\begin{array}{l}-2.879 * * * \\
(2.776)\end{array}$ & $\begin{array}{l}-1.617 \\
(0.917)\end{array}$ & $\begin{array}{l}-0.399 \\
(0.929)\end{array}$ & $\begin{array}{l}-8.470^{* * *} \\
(9.134)\end{array}$ & $\begin{array}{l}10.174 * * * \\
(4.549)\end{array}$ & $\begin{array}{l}-41.310^{* * *} \\
(4.633)\end{array}$ & $\begin{array}{l}-6.550 \\
(1.520)\end{array}$ & $\begin{array}{l}9.643 * * * \\
(4.896)\end{array}$ & $\begin{array}{l}-39.049 * * * \\
(2.896)\end{array}$ \\
\hline GFC & $\begin{array}{l}0.205^{* * *} \\
(4.076)\end{array}$ & $\begin{array}{l}-0.206 \\
(1.047)\end{array}$ & $\begin{array}{l}-0.564^{*} \\
(1.993)\end{array}$ & $\begin{array}{l}0.220 * * * \\
(5.308)\end{array}$ & $\begin{array}{l}0.856 * * * \\
(3.211)\end{array}$ & $\begin{array}{l}-0.032 \\
(0.549)\end{array}$ & $\begin{array}{l}-0.769 * * \\
(3.608)\end{array}$ & $\begin{array}{l}-0.123^{* *} \\
(3.289)\end{array}$ & $\begin{array}{l}-0.042 \\
(0.897)\end{array}$ & $\begin{array}{l}-1.891^{* * *} \\
(4.141)\end{array}$ \\
\hline Schools & $\begin{array}{l}0.030^{*} \\
(1.683)\end{array}$ & $\begin{array}{l}0.278 * * * \\
(26.764)\end{array}$ & $\begin{array}{l}0.305^{* * *} \\
(4.717\end{array}$ & $\begin{array}{l}0.043^{* *} \\
(1.962)\end{array}$ & $\begin{array}{l}0.431^{* * *} \\
(13.490)\end{array}$ & $\begin{array}{l}0.056^{* *} \\
(2.339)\end{array}$ & $\begin{array}{l}-0.377 * * * \\
(9.634)\end{array}$ & $\begin{array}{l}0.198 \\
(1.394)\end{array}$ & $\begin{array}{l}0.076^{* * *} \\
(3.282)\end{array}$ & $\begin{array}{l}-0.342^{* * *} \\
(8.080)\end{array}$ \\
\hline SchoolT & $\begin{array}{l}-0.064^{* * *} \\
(4.757)\end{array}$ & $\begin{array}{l}-0.047 \\
(2.860)\end{array}$ & $\begin{array}{l}-0.175 \\
(1.717)\end{array}$ & $\begin{array}{l}-0.057 * * * \\
(3.542)\end{array}$ & $\begin{array}{l}0.149 * * * \\
(4.773)\end{array}$ & $\begin{array}{l}0.022 \\
(1.033)\end{array}$ & $\begin{array}{l}-0.076 \\
(1.531)\end{array}$ & $\begin{array}{l}0.008 \\
(0.243)\end{array}$ & $\begin{array}{l}0.043^{*} \\
(1.694)\end{array}$ & $\begin{array}{l}-0.013 \\
(0.096)\end{array}$ \\
\hline Service & $\begin{array}{l}-0.104 * * * \\
(5.304)\end{array}$ & $\begin{array}{l}-0.129 \\
(1.043)\end{array}$ & $\begin{array}{l}0.073 \\
(0.562)\end{array}$ & $\begin{array}{l}-0.132 * * * \\
(3.509)\end{array}$ & $\begin{array}{l}-0.617 * * * \\
(4.226)\end{array}$ & $\begin{array}{l}0.124 * * * \\
(2.942)\end{array}$ & $\begin{array}{l}-0.321^{* * *} \\
(4.255)\end{array}$ & $\begin{array}{l}0.069 \\
(0.401)\end{array}$ & $\begin{array}{l}0.162 * * * \\
(3.986)\end{array}$ & $\begin{array}{l}-0.203^{*} \\
(2.489)\end{array}$ \\
\hline OPEN & $\begin{array}{l}0.057 * * * \\
(11.835)\end{array}$ & $\begin{array}{l}0.022 \\
(1.072)\end{array}$ & $\begin{array}{l}-0.014 \\
(1.068)\end{array}$ & $\begin{array}{l}0.068 * * * \\
(10.516)\end{array}$ & $\begin{array}{l}0.421^{* * *} \\
(6.755)\end{array}$ & $\begin{array}{l}0.005 \\
(0.596)\end{array}$ & $\begin{array}{l}0.022 \\
(0.782)\end{array}$ & $\begin{array}{l}0.047^{*} \\
(1.933)\end{array}$ & $\begin{array}{l}-0.040 * * \\
(2.414)\end{array}$ & $\begin{array}{l}-0.490^{* * *} \\
(5.517)\end{array}$ \\
\hline DEMO & $\begin{array}{l}0.719 * * * \\
(4.695)\end{array}$ & $\begin{array}{l}-0.692 \\
(1.007)\end{array}$ & $\begin{array}{l}-0.854 \\
(1.568)\end{array}$ & $\begin{array}{l}0.751^{* * *} \\
(5.177)\end{array}$ & $\begin{array}{l}0.673 \\
(1.127)\end{array}$ & $\begin{array}{l}-0.030 \\
(0.344)\end{array}$ & $\begin{array}{l}2.727 * * * \\
(21.220)\end{array}$ & $\begin{array}{l}-0.407 \\
(0.890)\end{array}$ & $\begin{array}{l}-0.028 \\
(0.347)\end{array}$ & $\begin{array}{l}0.399 \\
(1.092)\end{array}$ \\
\hline Shadow & & $\begin{array}{l}0.300 * * * \\
(5.291)\end{array}$ & $\begin{array}{l}1.714^{* * *} \\
(3.965)\end{array}$ & & $\begin{array}{l}0.309 * * * \\
(6.652)\end{array}$ & & $\begin{array}{l}0.506 \\
(1.702)\end{array}$ & $\begin{array}{l}2.750 * * * \\
(7.838)\end{array}$ & & $\begin{array}{l}-0.024 \\
(0.072)\end{array}$ \\
\hline Shadow*CPI & & & $\begin{array}{l}-0.185 * * * \\
(3.110)\end{array}$ & & & & & $\begin{array}{l}-0.363 * * * \\
(5.200)\end{array}$ & & \\
\hline CPI*OPEN & & & & $\begin{array}{l}-0.003 \\
(1.167)\end{array}$ & $\begin{array}{l}-0.061 * * * \\
(6.660)\end{array}$ & & & & $\begin{array}{l}0.007 * * * \\
(3.173)\end{array}$ & $\begin{array}{l}0.054^{* * *} \\
(5.955)\end{array}$ \\
\hline Constant & $\begin{array}{l}24.075 * * * \\
(4.779)\end{array}$ & $\begin{array}{l}46.666 * * * \\
(3.166)\end{array}$ & $\begin{array}{l}6.974 \\
(0.237)\end{array}$ & $\begin{array}{l}25.829 * * * \\
(4.002)\end{array}$ & $\begin{array}{l}38.135 * * * \\
(6.630)\end{array}$ & $\begin{array}{l}53.888 * * * \\
(2.985)\end{array}$ & $\begin{array}{l}415.184^{* * * *} \\
(5.928)\end{array}$ & $\begin{array}{l}-2.903 \\
(0.050)\end{array}$ & $\begin{array}{l}-49.698^{* * *} \\
(3.093)\end{array}$ & $\begin{array}{l}433.505^{* * *} \\
(4.203)\end{array}$ \\
\hline Adjusted $\mathrm{R}^{2}$ & 0.355 & 0.562 & 0.679 & 0.354 & 0.660 & 0.936 & 0.992 & 0.990 & 0.938 & 0.992 \\
\hline Wald test & 0.000 & 0.000 & 0.000 & 0.000 & 0.000 & 0.000 & 0.000 & 0.000 & 0.000 & 0.000 \\
\hline Observations & 180 & 27 & 27 & 180 & 27 & 180 & 27 & 27 & 180 & 27 \\
\hline Countries & 19 & 11 & 11 & 19 & 11 & 19 & 11 & 11 & 19 & 11 \\
\hline
\end{tabular}

Absolute $t$-statistics appear in parentheses with white heteroscedasticity corrected standard. ${ }^{* * *}, * *, *$ indicate significance level at the 1,5 and 10 percent, respectively. 
Table 3 Impact of corruption on inequality at different size of shadow economy

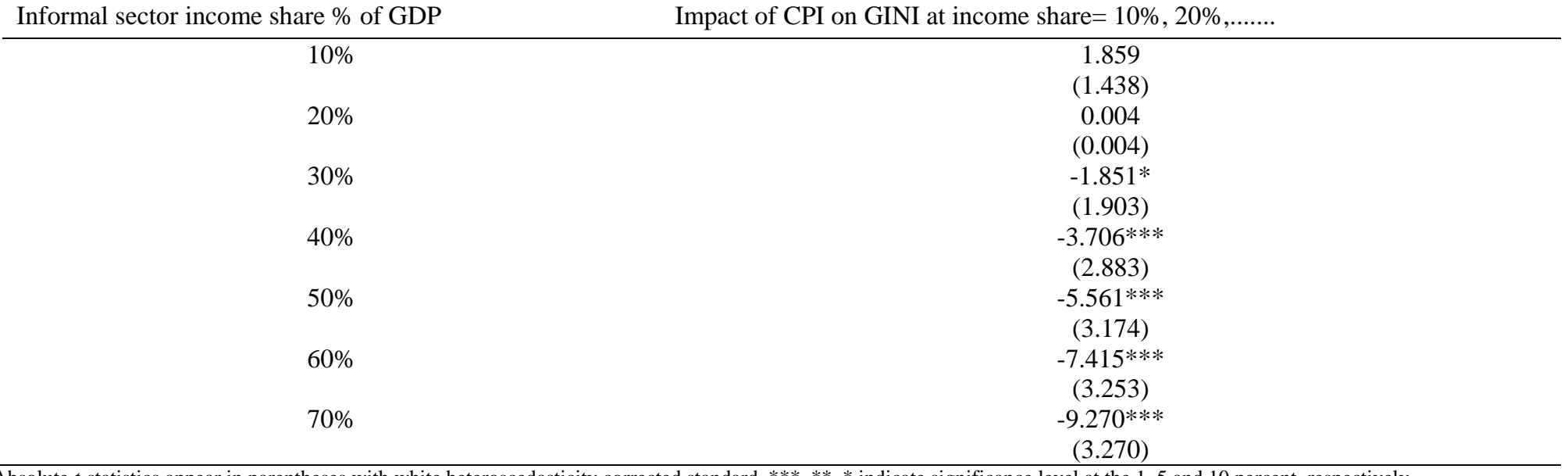

Absolute $t$-statistics appear in parentheses with white heteroscedasticity corrected standard. ***, **, * indicate significance level at the 1,5 and 10 percent, respectively. 
Table 4 Inequality and corruption using ICRG's Corruption index

\begin{tabular}{|c|c|c|c|c|c|}
\hline & FE (11) & FE (12) & FE (13) & FE (14) & FE (15) \\
\hline ICRG & $\begin{array}{l}0.247 \\
(1.096)\end{array}$ & $\begin{array}{l}-0.939 * * * \\
(20.521)\end{array}$ & $\begin{array}{l}0.454^{*} \\
(2.243)\end{array}$ & $\begin{array}{l}0.157 \\
(0.443)\end{array}$ & $\begin{array}{l}-2.027 * * * \\
(10.711)\end{array}$ \\
\hline LnGPPPC & $\begin{array}{l}9.319 * * * \\
(4.888)\end{array}$ & $\begin{array}{l}-81.156^{* * *} \\
(4.834)\end{array}$ & $\begin{array}{l}-59.356^{* *} \\
(3.907)\end{array}$ & $\begin{array}{l}9.403 * * * \\
(4.944)\end{array}$ & $\begin{array}{l}-34.090 \\
(1.261)\end{array}$ \\
\hline GFC & $\begin{array}{l}0.051 \\
(0.725)\end{array}$ & $\begin{array}{l}-2.549 * * * \\
(18.525)\end{array}$ & $\begin{array}{l}-1.868^{* * *} \\
(9.191)\end{array}$ & $0.046(0.636)$ & $\begin{array}{l}-2.605 * * * \\
(6.656)\end{array}$ \\
\hline SchoolS & $\begin{array}{l}0.113^{* * *} \\
(2.949)\end{array}$ & $\begin{array}{l}-0.467 * * * \\
(11.163)\end{array}$ & $\begin{array}{l}-0.218 * * \\
(3.995)\end{array}$ & $\begin{array}{l}0.108^{* *} \\
(2.418)\end{array}$ & $\begin{array}{l}-0.469 * * * \\
(6.451)\end{array}$ \\
\hline SchoolT & $\begin{array}{l}0.006 \\
(0.237)\end{array}$ & $\begin{array}{l}0.486 \\
(1.821)\end{array}$ & $\begin{array}{l}0.320 \\
(1.216)\end{array}$ & $\begin{array}{l}0.002 \\
(0.082)\end{array}$ & $\begin{array}{l}0.317 \\
(1.086)\end{array}$ \\
\hline Service & $\begin{array}{l}0.251^{* * * *} \\
(3.991)\end{array}$ & $\begin{array}{l}-0.365^{* *} \\
(3.332)\end{array}$ & $\begin{array}{l}-0.218^{* *} \\
(3.194)\end{array}$ & $\begin{array}{l}0.259 * * * \\
(4.041)\end{array}$ & $\begin{array}{l}0.188 \\
(0.755)\end{array}$ \\
\hline OPEN & $\begin{array}{l}-0.005 \\
(0.436)\end{array}$ & $\begin{array}{l}-0.122^{* * *} \\
(4.793)\end{array}$ & $\begin{array}{l}-0.071^{* * *} \\
(5.569)\end{array}$ & $\begin{array}{l}-0.011 \\
(0.944)\end{array}$ & $\begin{array}{l}-0.250 * * * \\
(3.943)\end{array}$ \\
\hline DEMO & $\begin{array}{l}0.017 \\
(0.194)\end{array}$ & $\begin{array}{l}2.684 * * * \\
(13.425)\end{array}$ & $\begin{array}{l}2.375 * * * \\
(14.988)\end{array}$ & $\begin{array}{l}0.026 \\
(0.284)\end{array}$ & $\begin{array}{l}1.745 * * \\
(2.930)\end{array}$ \\
\hline Shadow & & $\begin{array}{l}0.343 \\
(1.123)\end{array}$ & $\begin{array}{l}0.358 * * \\
(7.838)\end{array}$ & & $\begin{array}{l}1.163 \\
(1.535)\end{array}$ \\
\hline Shadow*ICRG & & & $\begin{array}{l}-0.060 * * * \\
(2.662)\end{array}$ & & \\
\hline ICRG*OPEN & & & & $\begin{array}{l}0.001 \\
(0.597)\end{array}$ & $\begin{array}{l}0.028 * * \\
(3.100)\end{array}$ \\
\hline Constant & $\begin{array}{l}56.790 * * * \\
(3.156)\end{array}$ & $\begin{array}{l}707.635^{* * * *} \\
(5.726)\end{array}$ & $\begin{array}{l}519.940 * * * \\
(4.627)\end{array}$ & $\begin{array}{l}-56.986 * * * \\
(3.162)\end{array}$ & $\begin{array}{l}317.267 \\
(1.690)\end{array}$ \\
\hline Adjusted $\mathrm{R}^{2}$ & 0.929 & 0.990 & 0.991 & 0.927 & 0.982 \\
\hline Wald test & 0.000 & 0.000 & 0.000 & 0.000 & 0.000 \\
\hline Observations & 169 & 27 & 27 & 169 & 27 \\
\hline Countries & 18 & 11 & 11 & 18 & 11 \\
\hline
\end{tabular}

Absolute $t$-statistics appear in parentheses with white heteroscedasticity corrected standard. ${ }^{* * *}, * *, *$ indicate significance level at the 1 , 5 and 10 percent, respectively. 
Table 5 Inequality, corruption and shadow economy: TSLS

\begin{tabular}{|c|c|c|c|c|}
\hline & (16) & (17) & (18) & (19) \\
\hline CPI & $\begin{array}{l}1.212 * * * \\
(2.989)\end{array}$ & $\begin{array}{l}9.671^{* * * *} \\
(3.542)\end{array}$ & $\begin{array}{l}1.329 * * \\
(2.258)\end{array}$ & $\begin{array}{l}10.120 * * * \\
(2.756)\end{array}$ \\
\hline LnGPPPC & $\begin{array}{l}-0.276 \\
(0.761)\end{array}$ & $\begin{array}{l}3.267 \\
(1.104)\end{array}$ & $\begin{array}{l}-0.794 \\
(1.026)\end{array}$ & $\begin{array}{l}-11.919 * * * \\
(3.147)\end{array}$ \\
\hline GFC & $\begin{array}{l}0.190 * * * \\
(3.490)\end{array}$ & $\begin{array}{l}-2.231 * * * \\
(4.067)\end{array}$ & $\begin{array}{l}0.213 * * \\
(2.073)\end{array}$ & $\begin{array}{l}1.766^{* * *} \\
(2.549)\end{array}$ \\
\hline Schools & $\begin{array}{l}0.035^{*} \\
(1.841)\end{array}$ & $\begin{array}{l}0.560 * * * \\
(5.062)\end{array}$ & $\begin{array}{l}0.056 \\
(1.596)\end{array}$ & $\begin{array}{l}0.521^{* * *} \\
(3.950)\end{array}$ \\
\hline SchoolT & $\begin{array}{l}-0.065^{* * *} \\
(4.386)\end{array}$ & $\begin{array}{l}-0.707 * * * \\
(3.884)\end{array}$ & $\begin{array}{l}-0.052 * \\
(1.649)\end{array}$ & $\begin{array}{l}0.287 * * \\
(2.239)\end{array}$ \\
\hline Service & $\begin{array}{l}-0.115^{* * *} \\
(6.969)\end{array}$ & $\begin{array}{l}0.886 * * * \\
(3.032)\end{array}$ & $\begin{array}{l}-0.163^{* * *} \\
(3.110)\end{array}$ & $\begin{array}{l}-0.983^{* * *} \\
(3.238)\end{array}$ \\
\hline OPEN & $\begin{array}{l}0.055^{* * * *} \\
(9.881)\end{array}$ & $\begin{array}{l}-0.068 * \\
(2.044)\end{array}$ & $\begin{array}{l}0.073 * * * \\
(5.193)\end{array}$ & $\begin{array}{l}0.744 * * * \\
(3.223)\end{array}$ \\
\hline DEMO & $\begin{array}{l}0.711^{* * *} \\
(4.265)\end{array}$ & $\begin{array}{l}-0.301 \\
(1.693)\end{array}$ & $\begin{array}{l}0.752^{* * *} \\
(3.973)\end{array}$ & $\begin{array}{l}2.000 * \\
(1.798)\end{array}$ \\
\hline Shadow & & $\begin{array}{l}4.164 * * * \\
(4.468)\end{array}$ & & $\begin{array}{l}0.300 * * * \\
(3.445)\end{array}$ \\
\hline Shadow*CPI & & $\begin{array}{l}-0.514^{* * *} \\
(4.186)\end{array}$ & & \\
\hline CPI*OPEN & & & $\begin{array}{l}-0.004 \\
(1.430)\end{array}$ & $\begin{array}{l}-0.109 * * * \\
(3.175)\end{array}$ \\
\hline Constant & $\begin{array}{l}27.353^{* * * *} \\
(3.860)\end{array}$ & $\begin{array}{l}-98.147 * \\
(2.099)\end{array}$ & $\begin{array}{l}31.345^{* * *} \\
(3.241)\end{array}$ & $\begin{array}{l}18.045 \\
(0.563)\end{array}$ \\
\hline Adjusted $\mathrm{R}^{2}$ & 0.343 & 0.748 & 0.346 & 0.572 \\
\hline Wald test & 0.000 & 0.000 & 0.000 & 0.000 \\
\hline Observations & 171 & 23 & 171 & 27 \\
\hline Countries & 19 & 10 & 19 & 11 \\
\hline Instruments & 9 & 11 & & \\
\hline $\begin{array}{l}\text { p-vlaue } \\
\text { Sargan test }\end{array}$ & 0.526 & 0.238 & 0.206 & 0.233 \\
\hline
\end{tabular}

Sargan test

Absolute $t$-statistics appear in parentheses with white heteroscedasticity corrected standard. ${ }^{* * *},{ }^{* *}, *$ indicate significance level at the 1 , 5 and 10 percent, respectively. 
Table 6 Inequality, corruption and informal sector in South Asian countries

\begin{tabular}{|c|c|c|c|c|c|c|}
\hline & PLS (20) & PLS (21) & PLS (22) & PLS (23) & PLS (24) & PLS (25) \\
\hline CPI & $\begin{array}{c}1.402 * * * \\
(4.220)\end{array}$ & & $\begin{array}{l}1.143 * * * \\
(2.902)\end{array}$ & & $\begin{array}{l}4.809 * * * \\
(4.692)\end{array}$ & \\
\hline ICRG & & $\begin{array}{l}0.177 \\
(0.475)\end{array}$ & & $\begin{array}{l}0.072 \\
(0.168)\end{array}$ & & $\begin{array}{l}1.551 \\
(1.213)\end{array}$ \\
\hline LnGPPPC & $\begin{array}{l}-0.237 \\
(1.018)\end{array}$ & $\begin{array}{l}0.494 \\
(1.092)\end{array}$ & $\begin{array}{l}-0.541^{*} \\
(1.736)\end{array}$ & $\begin{array}{l}-0.606 \\
(1.201)\end{array}$ & $\begin{array}{l}-6.543^{* * *} \\
(5.201)\end{array}$ & $\begin{array}{l}-4.019 * * \\
(2.114)\end{array}$ \\
\hline GFC & $\begin{array}{l}0.201^{* * * *} \\
(3.543)\end{array}$ & $\begin{array}{l}0.035 \\
(0.734)\end{array}$ & $\begin{array}{l}0.221 * * * \\
(4.472)\end{array}$ & $\begin{array}{l}0.054 \\
(1.017)\end{array}$ & $\begin{array}{l}0.145 \\
(0.427)\end{array}$ & $\begin{array}{l}-0.163 \\
(0.541)\end{array}$ \\
\hline SchoolS & $\begin{array}{l}0.001 \\
(0.067)\end{array}$ & $\begin{array}{l}-0.027 \\
(1.567)\end{array}$ & $\begin{array}{l}-0.0007 \\
(0.040)\end{array}$ & $\begin{array}{l}-0.024 \\
(1.291)\end{array}$ & $\begin{array}{l}0.534 * * * \\
(10.468)\end{array}$ & $\begin{array}{l}0.401^{* * *} \\
(3.818)\end{array}$ \\
\hline SchoolT & $\begin{array}{l}-0.072 * * * \\
(5.080)\end{array}$ & $\begin{array}{l}-0.060 * * * \\
(4.514)\end{array}$ & $\begin{array}{l}-0.067 * * * \\
(4.623)\end{array}$ & $\begin{array}{l}-0.059 * * * \\
(4.384)\end{array}$ & $\begin{array}{l}0.049 \\
(0.639)\end{array}$ & $\begin{array}{l}-0.079 \\
(0.853)\end{array}$ \\
\hline Service & $\begin{array}{l}-0.073^{* * *} \\
(3.523)\end{array}$ & $\begin{array}{l}-0.093^{* * *} \\
(4.261)\end{array}$ & $\begin{array}{l}-0.082 * * * \\
(3.886)\end{array}$ & $\begin{array}{l}-0.103^{* * *} \\
(3.996)\end{array}$ & $\begin{array}{l}-0.475^{* * *} \\
(2.839)\end{array}$ & $\begin{array}{l}-0.257 \\
(0.838)\end{array}$ \\
\hline OPEN & $\begin{array}{l}0.052 * * * \\
(11.513)\end{array}$ & $\begin{array}{l}0.038 * * * \\
(10.722)\end{array}$ & $\begin{array}{l}0.052 * * * \\
(11.822)\end{array}$ & $\begin{array}{l}0.039 * * * \\
(10.289)\end{array}$ & $\begin{array}{l}0.051 * * * \\
(4.331)\end{array}$ & $\begin{array}{l}0.020 \\
(1.248)\end{array}$ \\
\hline DEMO & $\begin{array}{l}0.782 * * * \\
(4.671)\end{array}$ & $\begin{array}{l}0.591 * * * \\
(3.241)\end{array}$ & $\begin{array}{l}0.809 * * * \\
(4.910)\end{array}$ & $\begin{array}{l}0.628 * * * \\
(3.222)\end{array}$ & $\begin{array}{l}-0.818^{*} \\
(1.803)\end{array}$ & $\begin{array}{l}-0.432^{* * *} \\
(5.608)\end{array}$ \\
\hline DSA & $\begin{array}{l}-2.852 * * * \\
(4.578)\end{array}$ & $\begin{array}{l}-3.098^{* * *} \\
(4.101)\end{array}$ & $\begin{array}{l}-17.007 * * * \\
(3.084)\end{array}$ & $\begin{array}{l}-9.963^{* *} \\
(2.447)\end{array}$ & $\begin{array}{l}10.023^{*} \\
(2.027)\end{array}$ & $\begin{array}{l}5.801 * * * \\
(4.067)\end{array}$ \\
\hline Shadow & & & & & $\begin{array}{l}1.625 * * * \\
(4.062)\end{array}$ & $\begin{array}{l}1.330 * * \\
(2.602)\end{array}$ \\
\hline CPI*DSA & & & $\begin{array}{l}1.810 * * * \\
(2.468)\end{array}$ & & $\begin{array}{l}0.032 \\
(0.058)\end{array}$ & \\
\hline ICRG*DSA & & & & $\begin{array}{l}0.100 \\
(1.594)\end{array}$ & & $\begin{array}{l}-0.542 \\
(1.286)\end{array}$ \\
\hline CPI*Shadow & & & & & $\begin{array}{l}-0.183^{* * *} \\
(3.566)\end{array}$ & \\
\hline ICRG*Shadow & & & & & & $\begin{array}{l}-0.128 * \\
(1.945)\end{array}$ \\
\hline Constant & $\begin{array}{l}26.615^{* * *} \\
(5.545)\end{array}$ & $\begin{array}{l}43.374 * * * \\
(10.368)\end{array}$ & $\begin{array}{l}30.709 * * * \\
(5.322)\end{array}$ & $\begin{array}{l}44.603^{* * *} \\
(9.270)\end{array}$ & $\begin{array}{l}26.787 \\
(1.386)\end{array}$ & $\begin{array}{l}35.867 * * \\
(1.213)\end{array}$ \\
\hline Adjusted $\mathrm{R}^{2}$ & 0.365 & 0.265 & 0.372 & 0.265 & 0.750 & 0.722 \\
\hline Wald test & 0.000 & 0.000 & 0.000 & 0.000 & 0.000 & 0.000 \\
\hline Observations & 180 & 169 & 180 & 169 & 27 & 27 \\
\hline Countries & 19 & 18 & 19 & 18 & 11 & 11 \\
\hline
\end{tabular}

Absolute $t$-statistics appear in parentheses with white heteroscedasticity corrected standard. ***, **, * indicate significance level at the 1 , 5 and 10 percent, respectively. 
Table 7 Marginal impact of corruption on inequality for average size of shadow economy

$\begin{array}{lccc}\text { Country } & \begin{array}{c}\text { Average size of } \\ \text { shadow economy (as } \\ \text { \% of GDP) }\end{array} & \begin{array}{l}\text { Marginal impact of CPI } \\ \text { on inequality for } \\ \text { average size of SE }\end{array} & \begin{array}{l}\text { Marginal impact o } \\ \text { ICRG index on } \\ \text { inequality for aver } \\ \text { size of SE }\end{array} \\ \text { Bangladesh } & 36.6 & -1.8568^{*} & -3.6758^{*} \\ \text { India } & 24.3 & 0.3941^{*} & -2.1014^{*} \\ \text { Indonesia } & 21.36667 & 0.898899 & -1.18393 \\ \text { Iran } & 19.96667 & 1.155099 & -1.00473 \\ \text { Israel } & 22.86667 & 0.624399 & -1.37593 \\ \text { Jordon } & 20.5 & 1.0575 & -1.073 \\ \text { Kuwait } & 20.8 & 1.0026 & -1.1114 \\ \text { Malaysia } & 31.63333 & -0.9799 & -2.49807 \\ \text { Oman } & 19.36667 & 1.264899 & -0.92793 \\ \text { Pakistan } & 37.8 & -2.0764^{*} & -3.8294^{*} \\ \text { Philippines } & 44.5 & -3.3345 & -4.145 \\ \text { Saudi Arabia } & 19.06667 & 1.319799 & -0.88953 \\ \text { Singapore } & 13.4 & 2.3568 & -0.1642 \\ \text { South Korea } & 28.13333 & -0.3394 & -2.05007 \\ \text { Sri Lanka } & 45.9 & -3.5587 * & -4.8662 * \\ \text { Taiwan } & 26.56667 & -0.0527 & -1.84953 \\ \text { Thailand } & 53.36667 & -4.9571 & -5.27993 \\ \text { UAE } & 27.1 & -0.1503 & -1.9178 \\ \text { Yemen } & 28.3 & -0.3699 & -2.0714\end{array}$

* indicates South Asian countries.

Figure 1. Gini coefficient and corruption

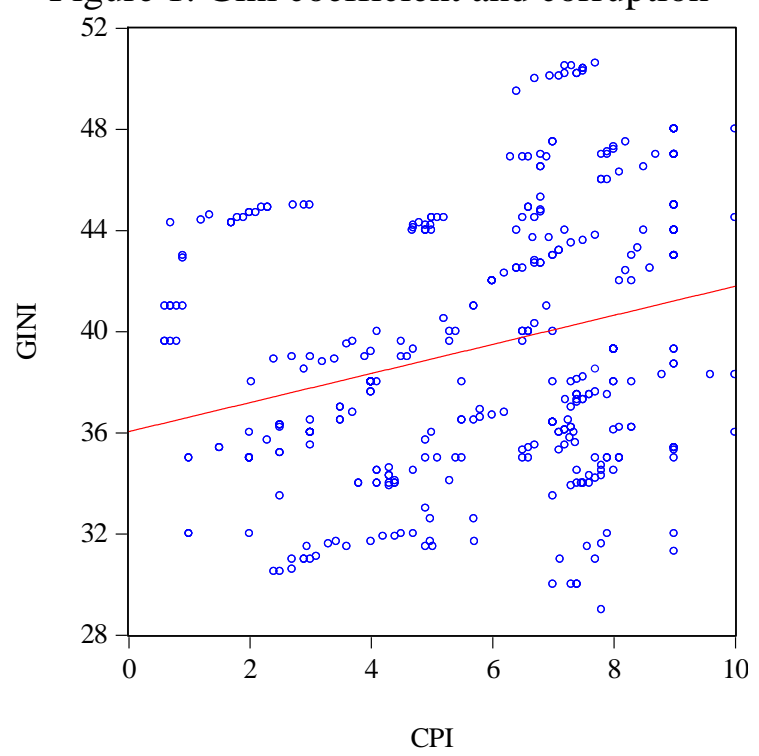


Figure 2. Corruption and Shadow economy

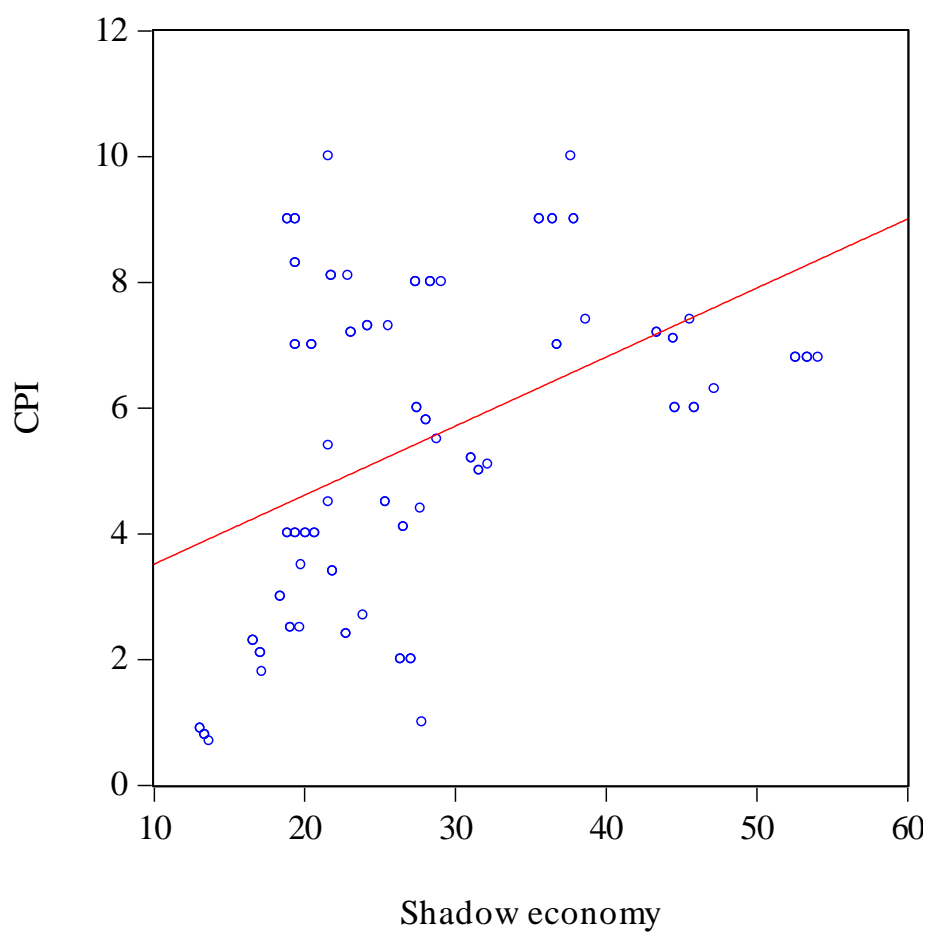

Figure 3. Gini coefficient and shadow economy

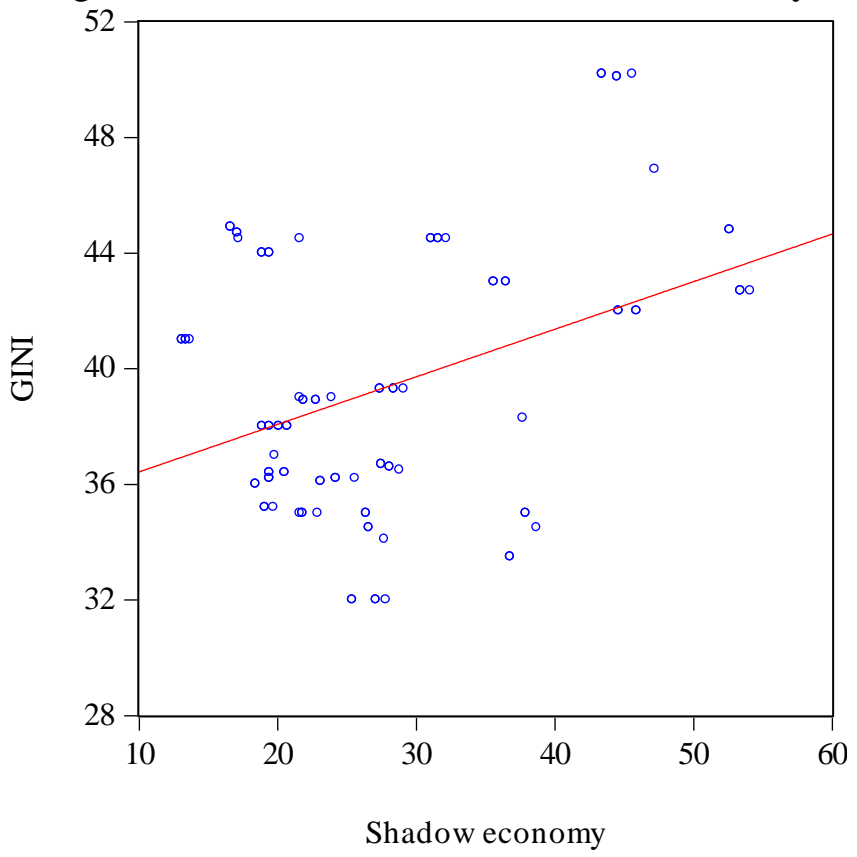

